Note

\section{Participation of Hydroxyl Radical in Hydroxylation of Pyridoxine by Ascorbic Acid}

\author{
Kenjiro Tadera, Midori Arima \\ and Fumio YAGI
}

\section{Laboratory of Biochemistry and Nutritional Chemistry, Department of Agricultural Chemistry, Faculty of Agriculture, Kagoshima University, \\ Korimoto 1-21-24, Kagoshima 890, Japan}

Received April 7, 1988

Food storage, processing and cooking reduce the content of biologically available vitamin $B_{6}$ in foods. ${ }^{1 \sim 4)}$ The mechanism of a loss of vitamin $B_{6}$ in plant foods is still obscure. We proposed a probable mechanism in which pyridoxine (PN) and $\mathrm{PN}$ conjugates were converted into 6hydroxypyridoxine (OPN) and OPN conjugates, respectively, in the presence of ascorbic acid (AsA). ${ }^{5)}$. In this paper, we showed that the hydroxyl radical $(\mathrm{OH} \cdot)$ generated during the autoxidation of AsA was responsible for the formation of OPN.

The disodium salt of 1,2-dihydroxybenzene-3,5-disulfonic acid (Tiron) was obtained from Wako Pure Chemical Industries, catalase (bovine liver) from Sigma Chemical Co., and all other reagents of the highest grade available from Nakarai Chemicals $L t d$.

A reaction mixture containing $4 \mathrm{mM} P N$ hydrochloride ( $\mathrm{PN} \cdot \mathrm{HCl}$ ), $2 \mathrm{~mm}$ sodium $\mathrm{AsA}$, and an additional reagent in $2.0 \mathrm{ml}$ of $0.1 \mathrm{M}$ acetate butffer, $\mathrm{pH} 5.0$, was placed in a vial $(12 \times 40 \mathrm{~mm})$ with a polypropylene cap, and then incubated at $30^{\circ} \mathrm{C}$ in the dark. AsA was gradually autoxidized under these conditions. After an appropriate incubation time, a $1-\mu 1$ sample of the reaction mixture was analyzed for OPN by the high-performance liquid chromatography described in our previous paper. ${ }^{5}$

OPN was formed from PN under aerobic conditions (Table I). The addition of $\mathrm{Cu}^{2+}$ or $\mathrm{Fe}^{2+}$ ion to the reaction mixture enhanced the formation of OPN (Table 1 and Fig. 1). As shown in Fig. 1, the reaction was rather rapid for the first $30 \mathrm{~min}$ in the presence of $\mathrm{Cu}^{2+}$ and $\mathrm{Fe}^{2+}$ ions. As to the effects of metal ion concentrations on the reaction rate, the $\mathrm{Cu}^{2+}$-mediated reaction proceeded more rapidly than the $\mathrm{Fe}^{2+}$-mediated one at concentrations ranging from $1 \times 10^{-7} \mathrm{M}$ to $1 \times 10^{-4} \mathrm{M}$. The reaction was inhibited by the chelating agent ethylenediaminetetraacetate (EDTA)(Table I). These results indicated that the formation of OPN was increased under the conditions which stimulated the autoxidation of AsA. Pyridoxal and 4'deoxypyridoxine were also hydroxylated under these conditions.
Since oxygen radicals are generated during the autoxidation of AsA, the effects of radical scavengers and a quencher on the formation of OPN were examined (reaction time: $24 \mathrm{hr}$ ). 2-Mercaptoethylamine (MEA), a scavenger for general radicals, ${ }^{6}$ completely depressed the reaction $\left(100 \%\right.$ inhibition by $1 \times 10^{-1} \mathrm{M}$ MEA, $96 \%$ by $1 \times 10^{-2} \mathrm{M}$, and $92 \%$ by $1 \times 10^{-3} \mathrm{M}$ ), indicating the direct participation of free radicals in the formation of OPN. 1,4Diazabicyclo[2.2.2]octane (DABCO), a specific quencher for $\mathrm{O}_{2},{ }^{7)}$ had little effect on the reaction $(19 \%$ inhibition by $1 \times 10^{-2} \mathrm{M} \mathrm{DABCO}$, and $0 \%$ by $\left.1 \times 10^{-3} \mathrm{M}\right)$. Among scavengers specific for $\mathrm{OH} \cdot,^{8)}$ potassium bromide, potassium iodide, and potassium thiocyanate strongly inhibited the reaction $\left(96 \%\right.$ inhibition by $1 \times 10^{-1} \mathrm{M} \mathrm{KBr}$,

\section{Table I. Effects of Oxygen, Metal Ion, Chelating Agent, Hydrogen Peroxide, and Catalase on Formation of 6-HYDROXYPYRIDOXINE}

A reaction mixture containing $4 \mathrm{~mm}$ pyridoxine hydrochloride, $2 \mathrm{~mm}$ sodium ascorbate, and an additional reagent in $2.0 \mathrm{ml}$ of $0.1 \mathrm{M}$ acetate buffer, $\mathrm{pH} 5.0$, was incubated at $30^{\circ} \mathrm{C}$ for $2 \mathrm{hr}$ in the dark. 6-Hydroxypyridoxine was measured by high-performance liquid chromatography. ${ }^{5)}$

\section{Addition} 6-Hydroxypyridoxine $(\mu \mathrm{M})$

$\begin{array}{lr}\text { None } & 58 \\ \text { None }\left(\mathrm{N}_{2} \text { gas }\right)^{a} & 0 \\ \mathrm{Cu}^{2+}\left(\mathrm{CuSO}_{4} \cdot 5 \mathrm{H}_{2} \mathrm{O}\right), 1 \times 10^{-5} \mathrm{M} & 194 \\ \mathrm{Fe}^{2+}\left(\mathrm{FeSO}_{4} \cdot 7 \mathrm{H}_{2} \mathrm{O}\right), 1 \times 10^{-5} \mathrm{M} & 106 \\ \mathrm{EDTA}^{b} 1 \times 10^{-4} \mathrm{M} & 11 \\ \text { Hydrogen peroxide, } 1 \times 10^{-3} \mathrm{M} & 167 \\ \text { Catalase, 300 units } & 5\end{array}$

a Nitrogen gas was bubbled through the reaction mixture during the incubation period.

b Ethylenediaminetetraacetate.

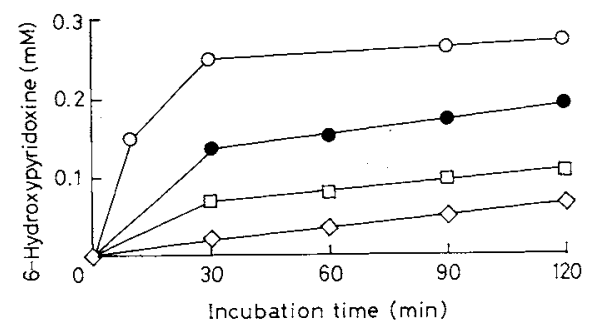

FIG. 1. Course of Formation of 6-Hydroxypyridoxine

A reaction mixture containing $4 \mathrm{~mm}$ pyridoxine hydrochloride, $2 \mathrm{~mm}$ sodium ascorbate, and $\mathrm{CuSO}_{4} \cdot 5 \mathrm{H}_{2} \mathrm{O}$ or $\mathrm{FeSO}_{4} \cdot 7 \mathrm{H}_{2} \mathrm{O}$ was incubated at $30^{\circ} \mathrm{C}$ in the dark. A $1-\mu \mathrm{l}$ sample of the reaction mixture was withdrawn at various times. $\diamond$, no addition of metal ions; $\bigcirc, 1 \times 10^{-4} \mathrm{M} \mathrm{Cu}^{2+}$; , $1 \times 10^{-5} \mathrm{M} \mathrm{Cu}^{2+} ; \square, 1 \times 10^{-5} \mathrm{M} \mathrm{Fe}^{2+}$. 
$78 \%$ by $1 \times 10^{-2} \mathrm{M}$, and $34 \%$ by $1 \times 10^{-3} \mathrm{M} ; 100 \%$ by $1 \times 10^{-1} \mathrm{M} \mathrm{KI}, 86 \%$ by $1 \times 10^{-2} \mathrm{M}$, and $66 \%$ by $1 \times 10^{-3} \mathrm{M}$; $100 \%$ by $1 \times 10^{-1}$ and $1 \times 10^{-2} \mathrm{M} \mathrm{KSCN}$, and $80 \%$ by $\left.1 \times 10^{-3} \mathrm{M}\right)$. Sodium formate showed lesser potency $(77 \%$ inhibition by $1 \times 10^{-1} \mathrm{M}$ HCOONa, and $33 \%$ by $\left.1 \times 10^{-2} \mathrm{M}\right)$. Tiron, a scavenger for the superoxide anion radical $\left(\mathrm{O}_{2}^{-}\right),{ }^{9}$ prevented the reaction $(100 \%$ inhibition by $1 \times 10^{-1} \mathrm{M}$ Tiron, $63 \%$ by $1 \times 10^{-2} \mathrm{M}$, and $34 \%$ by $\left.1 \times 10^{-3} \mathrm{M}\right)$. Since $\mathrm{O}_{2}^{-}$is closely related to the generation of $\mathrm{OH} \cdot$ as described below, $\mathrm{OH} \cdot$, but not $\mathrm{O}_{2}^{-}$, seemed to be responsible for the formation of OPN.

On autoxidation of AsA, $\mathrm{O}_{2}^{-}$is generated together with hydrogen peroxide $\left(\mathrm{H}_{2} \mathrm{O}_{2}\right),{ }^{10,11)}$ and $\mathrm{OH} \cdot$ generated as follows: ${ }^{6.12 \sim 14)}$

$\mathrm{AH}_{2}+\mathrm{O}_{2} \longrightarrow \mathrm{A}+\mathrm{H}_{2} \mathrm{O}_{2}$

$\mathrm{M}^{(n-1)+}+\mathrm{H}_{2} \mathrm{O}_{2} \longrightarrow \mathrm{M}^{n+}+\mathrm{OH}^{-}+\mathrm{OH}$.

(Fenton reaction)

$\mathrm{AH}_{2}+2 \mathrm{M}^{n+} \longrightarrow \mathrm{A}+2 \mathrm{M}^{(n-1)+}+2 \mathrm{H}^{+}$

$2 \mathrm{O}_{2}^{-}+2 \mathrm{H}^{+} \longrightarrow \mathrm{H}_{2} \mathrm{O}_{2}+\mathrm{O}_{2}$

$\mathrm{H}_{2} \mathrm{O}_{2}+\mathrm{O}_{2}^{-}-\rightarrow \mathrm{OH} \cdot+\mathrm{OH}^{-}+\mathrm{O}_{2}$

(Haber-Weiss reaction)

$\mathrm{M}^{n+}+\mathrm{O}_{2}^{-} \longrightarrow \mathrm{M}^{(n-1)+}+\mathrm{O}_{2}$

where $\mathrm{AH}_{2}$ is a reduced form of $\mathrm{AsA}, \mathrm{A}$ is dehydroascorbic acid, and $\mathrm{M}$ is copper or iron. The addition of $\mathrm{H}_{2} \mathrm{O}_{2}$ to the reaction mixture enhanced the formation of OPN, but catalase depressed the reaction (Table I). These results could be reasonably explained by an increase or decrease in the generation of $\mathrm{OH}$, as can be seen from the above equations.

Hydroxylation of $\mathrm{PN}$ by $\mathrm{OH}$ to give $\mathrm{OPN}$ was confirmed by a Fenton reaction. Incubation of $4 \mathrm{mM} \mathrm{PN} \cdot \mathrm{HCl}$ with $1 \mathrm{mM} \mathrm{H}_{2} \mathrm{O}_{2}$ and $1 \mathrm{mM} \mathrm{FeSO}_{4} \cdot 7 \mathrm{H}_{2} \mathrm{O}$ in $2.0 \mathrm{ml}$ of $0.1 \mathrm{M}$ acetate buffer, $\mathrm{pH} 5.0$, at $30^{\circ} \mathrm{C}$ for $20 \mathrm{~min}$ produced $\mathrm{OPN}$, but the removal of $\mathrm{Fe}^{2+}$ ion did not.

Oxygen radicals generated during the autoxidation of AsA bring about inactivation of phages, ${ }^{6,13 \sim 16)}$ DNAscission, ${ }^{17)}$ oxidative depolymerization of polysaccharides, ${ }^{18 \sim 22)}$ hydroxylation of aromatic compounds, ${ }^{23,24}$ and inactivation of enzyme. ${ }^{25)}$ The active oxygen radical species is shown to be $\mathrm{OH} \cdot$ in some cases. $^{6,14,22 \sim 25}$ ) This paper is the first to describe hydroxylation of PN by $\mathrm{OH} \cdot$ generated during the autoxidation of AsA.

\section{REFERENCES}

1) L. R. Richardson, S. Wilkes and S. J. Ritchey, J. Nutr., 73, 363 (1961).

2) H. A. Schroeder, Am. J. Clin. Nutr., 24, 562 (1971).

3) J. F. Gregory and J. R. Kirk, J. Food Nutr., 43, 1801 (1978).

4) J. F. Gregory and J. R. Kirk, Nutr. Rev., 39, 1 (1981).

5) K. Tadera, M. Arima, S. Yoshino, F. Yagi and A. Kobayashi, J. Nutr. Sci. Vitaminol., 32, 267 (1986).

6) A. Murata, H. Suenaga, M. Inoue, Y. Tanaka and F. Kato, Vitamins, 57, 515 (1983).

7) C. Ouannes and T. Wilson, J. Am. Chem. Soc., 90, 6527 (1968).

8) K. Asada, Seikagaku, 48, 226 (1976).

9) R. W. Miller and U. Rapp, J. Biol. Chem., 248, 6084 (1973).

10) K. Puget and A. M. Michelson, Biochimie, 56, 1225 (1974).

11) M. Scarpa, R. Stevanato, P. Viglino and A. Rigo, $J$. Biol. Chem., 258, 6695 (1983).

12) A. Murata, Tanpakushitsu Kakusan Koso, 20, 593 (1975).

13) K. Wong, A. R. Morgan and W. Paranchych, Can. J. Biochem., 52, 950 (1974).

14) A. Murata, H. Suenaga, S. Hideshima, Y. Tanaka and F. Kato, Agric. Biol. Chem., 50, 1481 (1986).

15) A. Murata, K. Kitagawa and R. Saruno, Agric. Biol. Chem., 35, 294 (1971).

16) A. Murata and K. Kitagawa, Agric. Biol. Chem., 37, 1145 (1973).

17) S. -H. Chiou, J. Biochem., 96, 1307 (1984).

18) G. Matsumura and W. Pigman, Arch. Biochem. Biophys., 110, 526 (1965).

19) A. Herp, T. Richards, G. Matsumura, L. B. Jakosalem and W. Pigman, Carbohydr. Res., 4, 63 (1967).

20) S. F. Wong, B. Halliwell, R. Richmond and W. R. Skowroneck, J. Inorg. Biochem., 14, 127 (1981).

21) K. Uchida and S. Kawakishi, Agric. Biol. Chem., 50, 367 (1986).

22) K. Uchida and S. Kawakishi, Agric. Biol. Chem., 50, 2579 (1986).

23) S. Senoh, C. R. Creveling, S. Udenfriend and B. Witkop, J. Am. Chem. Soc., 81, 6236 (1959).

24) A. Slivka and G. Cohen, J. Biol. Chem., 260, 15466 (1985).

25) E. Shinar, T. Navok and M. Chevion, J. Biol. Chem., 258, 14778 (1983). 